\title{
Professional Identity in Analysis: A Systematic Review of the Literature
}

\author{
Inês Cardoso ${ }^{1, *}$, Paula Batista ${ }^{1,2}$ and Amândio Graça ${ }^{1,2}$ \\ ${ }^{I}$ Faculty of Sport, University of Porto, Portugal \\ ${ }^{2}$ CIFI2D, Centre for Research, Education, Innovation and Intervention in Sport, University of Porto, Portugal
}

\begin{abstract}
The present study is a systematic review of literature, with the objective to map the typology of conceptual studies about professional identity, as well as the used conceptual fields and the evidence therefrom resulting. The research was made within the electronic databases ISI web of Knowledge, EBSCO (Academic Search Complete, ERIC and Sport Discus) and B-On, between 2002 and 2011. The research equation was "Professional Identity" AND "Review", in the fields 'abstract', 'topic' and 'title' having been integrated 22 articles. The content analysis was the technique used, with the following categories defined $a$ priori: i) typology studies; (ii) conceptual framework around the professional identity; iii) indications for future researches about teacher's identity. The results showed a marked increase of publications in 2011, in large professional areas (teachers and nurses) and in two main stages of development (the learning and professional process), as well as a strong conceptual positioning of authors in the perspective of symbolic interactionism and in post-modernity. It was also clear that the concept of professional identity fits simultaneously in individual (personal and social) and collective dimensions. Indeed, it involves the individual, his/her relationship with the other in a given context and his/her sense of belonging to a group. Regarding the proposals for future investigations, the researches with a qualitative nature (ethnographic and longitudinal) in work places prevails, with emphasis on the observation of dynamics established in communities of practice and its speeches (public and private), in a combination of micro and macro analysis.
\end{abstract}

Keywords: Identity, professional identity, perspectives of identity, systematic review.

\section{INTRODUCTION}

The research around the professional Identity is wide [15], and runs through multiple areas of intervention, such as philosophy and psychology [6,7], social psychology $[8,9]$ and sociology $[10,11]$. Within this broad investigative spectrum co-exist several understandings and perspectives, beginning with the concept of identity itself. In fact, several concepts of identity merged within different perspectives (functionalism, cognitivist, symbolic interactionism, poststructuralism), associated with the different visions (modernity, post-modernity) that must be clarified. In addition to the different perspectives, different notions emerge around identity's concept. Actually, one must has to have in consideration not only the idea of identity as unique and unmistakable (resulting from the social reproduction within modernity) - disseminated by Durkheim [12] - but also as a construct developed along life, under contextual influences (related to post-modernity) [8]. The variability of concepts that are associated with the construct of identity

*Address correspondence to this author at the Faculty of Sport, University of Porto, Portugal; Tel: 351225074778; Fax: 351225500689;

E-mail: inestcardoso@gmail.com (e.g., self, discourse, narrative, structure, agency, reflection, emotional aspect) gives it a high complexity.

In this framework, and in the pursuit of a better understanding of this problem, it is important to revisit the concept of identity. Currently, this construct lines up a multiple character, for the reason that it can no longer be understood as a fixed attribute of a particular person, neither be regarded as an element of a dynamic nature, relational, situational and object of inference [1, 2, 13, 14]. Moreover, everyone has multiple identities interacting with each other [13] by a 'core identity' [6], that even in different contexts relay within certain uniformity. Alongside, the theories of identity $[9,15]$ attribute two dimensions to the concept: the individual and the collective. The individual dimension covers two aspects: a) a personal aspect, concerning the internalization of social positions and their meanings as part of the structure of the self; and b) a social aspect, related to the impact of cultural meanings and social situations in the identification of an individual with a group $[8,11]$. In turn, the collective dimension is related to the processes triggered at the level of mobilization of a joint action on a shared purpose among elements of the same group [10]. For this reason, the two strands of individual identity (personal and social) and the collective identity constitute what Owens, 
Robinson and Smith-Lovin [15] denominate the 'Three faces of identity'.

When referring to the theories of identity, one has to take into account the individual dimension - affiliated to interactionism, in which Mead [7] is a reference. The understanding of this author brings us to the relationship between the concept of identity and the concept of self, in which the ability of an individual to imagine himself/herself under the point of view of another to subdivide the self in two components: the ' $\mathrm{I}$ ' and the 'me', is underlined. The ' $\mathrm{I}$ ' (or individual) corresponds to the singular aspect, spontaneous and dynamic of the self (self as knower), being considered a more personnel component. The 'me' (or object) matches the learned prospects that a person incorporates in herself/himself (self as known) and the attitudes that the 'I' integrates, considered as a more social component. The self it is, therefore, a phenomenon of the human mind that arises from the reflexive action arising from interactions that an individual establishes with others. Its reflective character comes from the self considered as an object that can be categorized, classified or named in a particular way in relation to other social categories or classifications [9]. This process of identity construction is called 'self-categorization' in the theory of social identity and 'identification' in theory of identity. With the social identity theory (related to identification with a group) we are able to know 'who is' a specific individual. The identity theory (related with the role assumed ${ }^{1}$ ) allows to determine 'what does' this individual. 'Being' and 'doing' become two central characteristics of the identity of the person. The result of the joinder 'being' and 'doing', between perceptions and behaviours, between reflection and agency, promotes selfdevelopment through the transactions that each one establishes with the social environment. The dynamics of these transactions is determined by life options ${ }^{2}$, which are directly dependent on individual decisions, not only on the way to 'act', but also about 'whom to be'. Giddens [11] reinforces the importance of individual decision-making: "what the individual becomes depends on the reconstructive efforts that he is engaged" (p. 70). This is why it is so highly valued the individuals' active participation in the construction of his/her identity. Additionally, the active participation, in the understanding of Stets and Burke [9], requires motivational processes of self-efficacy (according to the theory of identity), and self-esteem (according to the theory of social identity), which in turn depends on the identification of the subject with the social role. This identification (based on language between the self and the social role assumed) constitutes a central motivation for the human being, through the reflective character of the self, to be faced with alternative options of commitments and actions [15]. In other words, it is through the language (selfdialogue) that it is possible to understand the past actions and, from this understanding, to act in the present and plan the future. Thus, the subjects perceive not only what they are doing (related to the role and with the self-efficacy), but also

\footnotetext{
${ }^{1}$ Role assumed: social position that a person acquires in a social structure [15] ${ }^{2}$ Life options: more or less integrated set of practices which an individual embraces, not only because such practices fulfil utilitarian needs, but because form his self-identity
} [11] who they are and who they want to be (related to identification with a social group and with the self-esteem). Alongside, this idea is closely linked with the social aspect of individual identity, where professional identities fall, in so far as the individuals project their identity in identification with a professional group, using their ability to choose 'what' they want to be in the future (anticipatory socialization ${ }^{3}$ ), and 'how' they want to be (anticipatory reflection ${ }^{4}$ ). Sfard and Prusak [17] refer to these identities as 'designated identities, , which result from the choice of identification of the individual with a particular professional group. Throughout these 'designated identities', professional identity is understood as a dynamic discursive process $^{6}$ of interpretation and reinterpretation of experiences $[14,18$, 19], in a permanent communication between the individual and the situation. This dynamic and evolving character of professional identity is portrayed by Jebril [20] with four development stages: (i) level of preoccupation, which is divided into two phases (preparatory and exploratory) and takes place during childhood and adolescence, when the anticipatory socialization plays a major role; (ii) learning stage (to be able to relate the self with the profession), which corresponds to the phase in which the construction of professional identity is at its highest level, and in which the individual is identified with the chosen profession; (iii) professional stage, which closes the gap between theory and practice, and corresponds to the phase of accumulation of experience and strengthening of professional identity, in which the individual uses the anticipatory reflection to reinterpret the experiences of the past, and from this reinterpretation quotes the future action; (iv) postprofessional stage, which represents the changes of professional identity after the reform. For this reason, the professional identity can be the person's social identity (when this person is identified with a professional group and when assumes the respective role: 'be' and 'make'), and mobilizes a joint action (when there is a sense of common destiny within the group). When people take the same identity, are experiencing the same reality and observe mutual emotions, growing a sense of common destiny and of empathy, which mobilizes the joint action [15]. It is precisely this joint action that allows distinguishing social identity from collective identity.

Regarding collective identity - characterized by joint action and the sharing of meanings and social representations about a given profession, both at a local and global level the concept of communities of practice ${ }^{7}$ gains importance. The constituent elements of these communities share knowledge and contribute to the construction of collective

\footnotetext{
${ }^{3}$ Anticipatory socialization: process of personal projection on a future career by identifying members of a reference group [8].

${ }^{4}$ Anticipatory reflection: looking to the future with the knowledge of the past through the point of view of the present; the recall of past experience allows us to anticipate future experiences [16].

${ }^{5}$ Designated identities: "stories believed to have the potential to become a part of one's actual identity. They can be recognized by their use of the future tense or of words that express wish, commitment, obligation, or necessity, such as should, ought, have to, must, want, can, cannot, and so forth. Narratives such as "I want to be a doctor" or "I have to be a better person" are typical of designated identities" [17].

${ }^{6}$ Dynamic discursive process: "sociocultural perspective in which a person's identity is shaped and negotiated through everyday activities" [14].

${ }^{7}$ Community of practice: experiences in a real context of professional practice conducted in groups; it is a space where sharing is essential for success [21].
} 
Table 1. Category of analysis.

\begin{tabular}{|c|c|c|c|c|c|c|c|}
\hline \multirow{2}{*}{ Author/ year } & \multirow{2}{*}{ i) Journal } & \multicolumn{4}{|c|}{$\begin{array}{c}\text { ii) } \\
\text { Theoretical Framework }\end{array}$} & \multirow{2}{*}{$\begin{array}{c}\text { iii) } \\
\text { professional area of application and } \\
\text { development stages }\end{array}$} & \multirow{2}{*}{$\begin{array}{l}\text { iv) } \\
\text { methodological proposals } \\
\text { for future studies }\end{array}$} \\
\hline & & $\begin{array}{c}\text { authors } \\
\text { cited }\end{array}$ & $\begin{array}{c}\text { related } \\
\text { concepts }\end{array}$ & $\begin{array}{l}\text { research } \\
\text { fields }\end{array}$ & $\begin{array}{c}\text { theoretical } \\
\text { perspectives }\end{array}$ & & \\
\hline
\end{tabular}

understandings, as a result of mutual relations of participation.

Faced with this framework it is noticeable that the individual and collective dimensions of identity are reflected in the professional identity, namely in the teacher's identity. Thus, in this study we intend to examine the conceptual field of professional identity in order to withdraw inferences to the teacher professional identity. The guiding research questions are:

1. Which conceptual studies typology has been developed about the professional identity?

2. Which conceptual and understandings field shapes the research about professional identity?

3. What evidences have resulted from the studies conducted in the field of professional identity and what implications bring for understanding the teacher's identity?

\section{METHODOLOGY}

\subsection{Research Context: from Selection to the Analysis Procedures}

A process of systematic review was used in order to identify and to synthesize relevant literature about a particular topic [22, 23], in this case theoretical evidences about professional identity. Petticrew and Roberts [23] state that the use of this methodology allows to perform structured and clarifying an aggregation of data from studies of different nature and areas, identifying main ideas, models and debates in a particular field, capturing the context, processes and subjective elements of the topic. In line with this approach, we first conducted an extensive database search to identify theoretical and review articles submitted to peer-reviewed journals focused on professional identity.

\subsection{Search Methods}

A search of research papers between January 2002 and December 2011 was conducted via ISI web of Knowledge, EBSCO (Academic Search Complete, ERIC e Sport Discus) and B-On, using the following keywords/subject terms: "Professional Identity" AND "Review". The search field in databases were 'abstract', 'topic' and 'title', depending on the databases. The inclusion of all the databases including Bon was to ensure that all relevant international literature was identified. Afterwards, the outcomes of each search were examined in order to identify scientific theoretical and review papers findings with regard the construct of professional identity in different areas. Empirical studies were excluded. Studies without in-depth approaches reporting to professional identity were also discarded due to the aim and focus of the review. Two researchers independently assessed relevant studies for inclusion using the selection criteria mentioned above. Any disagreements were resolved by discussion. When the abstract was deemed not to give sufficient information, the full paper was retrieved and examined prior to final decision-making about inclusion or exclusion.

\subsection{Search Outcome}

The search results $(\mathrm{n}=121)$ were imported into EndNote X6, bibliographic management system software. Fig. (1) shows the refinement process into the final 22 papers that were included in the review.

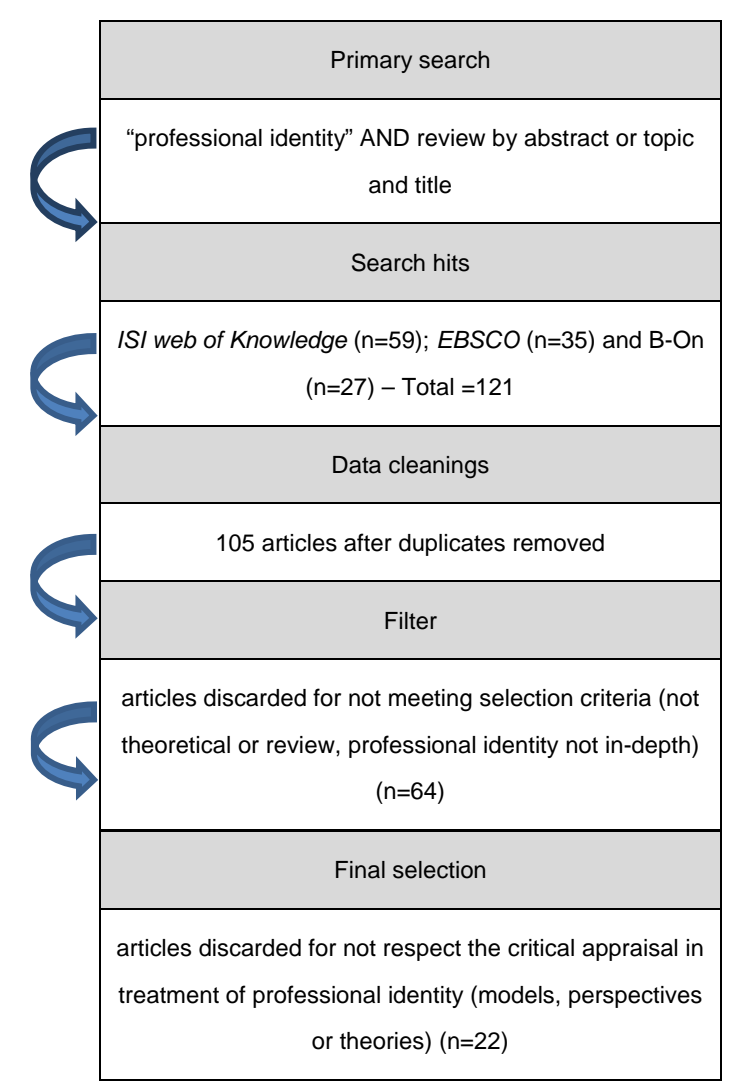

Fig. (1). Flowchart of the literature search process.

\subsection{Quality Appraisal}

In line with the aim of the research, we undertook as critical appraisal the papers that made a deep treatment of professional identity construct supported by models, perspectives or theories about identity.

\subsection{Data Abstraction}

Basic details of these research-based studies are given in Table $\mathbf{1}$ along with the coverage of the studies using the 


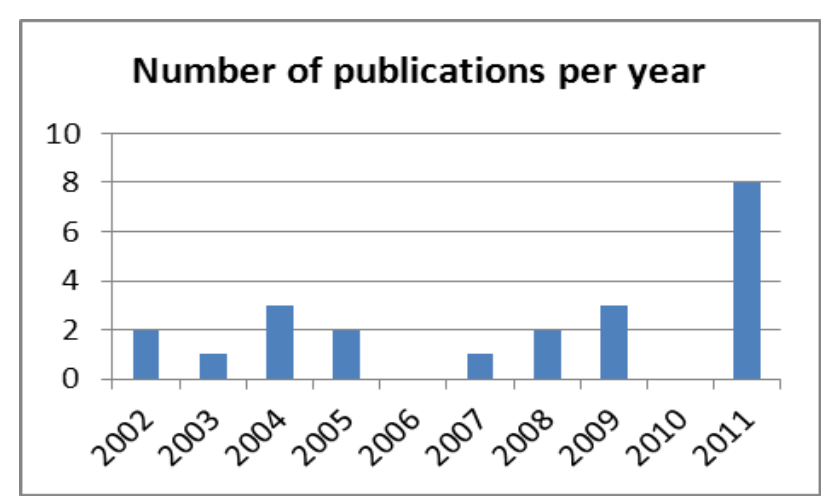

Fig. (2). Number of publications about professional identity between the years $2002-2011$.

following descriptors: i) journal of publication; ii) theoretical framework, which includes the authors cited, related concepts, research fields and theoretical perspectives; iii) professional areas of application and development stages [20]; and iv) methodological perspective regarding the directions for future research.

\subsection{Synthesis}

The information collected and systematized according with the descriptors was subsequently organized into three major components: (i) typology of studies; (ii) conceptual framework around professional identity; and (iii) indications for future investigations about teacher's professional identity.

The component 'typology of studies' incorporates characterization data (publications per year and places of the globe where they were conducted), professional areas of application (teachers and nurses) and fields of research (philosophical, psychological, sociological, historical and anthropological) [24], and theoretical perspectives in focus (e.g., functionalism [12], symbolic interactionism [7] and post-structuralism [25]).

The 'conceptual framework around professional identity' component takes into account: the similarities and dissimilarities between professionals areas (teachers and nurses), development stages (preoccupation stage, learning stage, professional stage and post-professional stage of Jebril [20]) and the concepts related to professional identity within the logic of 'three faces of identity' systematized by Owens, Robinson and Smith-Lovin [15]. That is, the personal face and the social face; together, both faces make up the individual identity and collective face, materialized in the collective identity.

The component 'directions for future investigations about teacher's identity' is examined in order to identify the paths proposed by the authors, as well as the methodological guidelines that need to be used in research about professional identity.

\section{RESULTS AND DISCUSSION}

\subsection{Typology of Studies}

At this point of analysis, it is mandatory to give a brief characterisation of the studies, taking into account the number of publications per year and the geographical location where the studies were carried out, followed by the professional areas of application, as well as the fields of research of different authors and theoretical perspectives in focus.

\subsubsection{Characterization Data: Number of Publications and Geographical Local were the Research was Made}

In a first analysis concerning the number of publications per year, stands out the absence of regularity. However, a sharp increase in 2011 is verifiable (Fig. 2).

The diversity of scientific journals in which the theme of professional identity has been object of publications, associated with the geographical extension in which the studies have been carried out, highlights the international concern with this theme. In fact, the 22 articles analysed were published in 20 different journals (magazines "Teaching and Teacher Education" and "Academy of Management Review" published two articles each one) and in three continents: Europe, America (North and South) and Australia.

\subsubsection{Professional Areas of Application and Research Fields}

From the analysis of occupational areas of application, it was evident that the studies relapsed mostly in teachers $(n=8)[1,2,13,26-30]$ and nurses $(n=7)$ [31-37]. Of the remaining seven studies, six [38-43] are not reported to any specific professional area. In these, their attention fell on trade-related aspects such as: the use of the internet in the choice of the future profession [43]; the perceiving that young professionals have of themselves and the way other professionals "see" them when entering the profession [39]; the influence of the guidelines of identity (personal, relational or collective) in social interactions of professionals in the exercise of the profession [40]; the professional image of individuals in workplaces [41]; the professional career construction in a position of independence regarding the organizations [38]; and the conceptualization of professional identity according to contemporary research [42]. Finally, a study [44] was focused on the need to construct an ethics code that ensures uniformity to the profession of librarian.

The research fields [24] did not differ significantly: in five studies the authors were focused in psychology [27, 33, $41,43,44]$, other five, in social psychology [13, 35, 36, 40, 42], eight, in sociology [26, 28, 29, 31, 32, 34, 37, 39] and four, in a "mixed" of research fields (philosophy, anthropology, psychology and sociology, psychosociology). The last four studies did not positioned in a particular field. For instances, Beijaard, Meijer and Verloop [2] presented a study of systematic review with the purpose of characterizing how the teacher's identity research evolved between 1988 and 2000; these studies were focused in the areas of psychology, philosophy, and sociology. Beauchamp and Thomas [1] conducted a review of the issues that involve the recent discussions about teacher's identity, in particular the problem of its conceptualization, the place occupied by self (and the questions that are listed as agency, emotion, narrative and discourse), the role of reflection and the influence of contextual factors; thus, covering the areas of philosophy, psychology, anthropology and sociology. 
Bendassolli [38] examined the relationship of the subjectwork in models of emerging career, based on the sociology of professions and the psychology of work. Finally, Mockler [30] developed a model to construct a teacher professional identity's conceptualization, in order to find a holistic approach to understand what is to 'being a teacher', using philosophy, psychology and sociology.

\subsubsection{Theoretical Perspectives in Focus}

The analysis of the studies revealed a strong positioning of authors in symbolic interactionism [1, 2, 13, 26, 28, 31, $32,35,37,38,40-42]$ and in post-modernity [26, 30, 31, 35, 38] associated with post-structuralism [34, 39, 43]. In fact, how the identity is interpreted has undergone profound changes as a result of the phenomenon of globalization, in which the uncertainty and instability are evident. Within this framework, the new identity begins to be defined as a process in permanent construction, and therefore, multiple, fluid, dynamic and simultaneously fragmented [25]. In the post-modern perspective, the identity is no longer to be understood as a dash of personality that characterizes determined individual, and begins to be seen as the product of the speech, imbued with a permanent reflection about the experiences, which, in turn, are influenced by power relations in multiple contexts $[10,11]$. This gaze on the identity is unequivocal among the studies analysed. Additionally, some authors portray their looming interactionism to valorise the reciprocal influences established between the individual and the context. These authors criticize the functionalism ${ }^{8}[29,30,33,37,39]$ when they consider that it is necessary to give individuals greater decisional autonomy, freeing them from existing sociocultural charges in some institutions. In these cases, the individuals have to comply with the contextual conditions, by which the influences cease to be reciprocal and become unilateral (imposed). However, the alternative post-modern identity provides instability within the game amid the internal influences (answer given to the attitudes of others) and external (set of attitudes of others that someone takes for himself). This instability poses problems to identity's regularity as a function of time and space (day after day and acting in different contexts). The question that arises is: given the evolving nature of identity concept, how does a person recognizes himself/ herself as being 'single' in different moments and acting in different contexts? The lack of answers from modern and post-modern perspectives to the recognition of a same identity over time and through different contexts, lead Akkerman and Meijer [13] to propose an alternative approach. The authors suggest the interpretation of identity as a dialogical process between post-modern and modern concepts, between multiple and single, the discontinuous and continuous and the social and the individual. At that point, the individual recognizes and it is recognized as one and the same person, despite the changes that 'suffers' and that 'causes', in the interaction that establishes with others in a particular historical, social and cultural context. These mutual influences between the

${ }^{8}$ Functionalism: perspective of socialization designed by Émile Durkheim in which society is seen as stable and the socialization process is understood to be outside the individual to the extent that "se trata de una socialización precoz que resulta en la interiorización del deber por imposición". [45]. individual and the context affect the identity, both at the individual level (personal component and social component), and at the community level, promoting its development. The interactions established between an individual and a particular group (e.g., professional group), by identification with its cultural and situational context, trigger the social aspect of individual identity [15]. When considering a professional group, the construction process of this professional identity involves the seamless integration of internal and external factors in a person's behaviour (self), which as a whole determines the professional self and develops the identification with the profession [20]. The integration of internal and external factors results in different personalities as well as in different professional identities, which are reflected in the undertaking and in the attitude toward the profession. This is a process that starts in childhood, by the cultural influences and experiences of learning (anticipatory socialization), and it is developed through a self-evolutionary, coherent and conscious manner. Nevertheless, it is also an unconsciously process that it is reconstructed in the interaction with the institutional and cultural context and with the people with whom children interact [13]. On the other hand, since we are dealing with an inter-relational process, the self influences the context and modifies it. This idea is consistent with the biographic and relational processes proposed by Dubar [8], to whom the biographical process concerns the "construction of social identities and professionals performed by individuals over time and from the categories offered by successive institutions (family, school, labour market, company etc.), which are both considered, accessible and valued; but the relational process is connected to the recognition, at a given time and in a given space of legitimacy, of identities associated with the knowledge, skills and images of himself, proposed and expressed by individuals in the systems of action" (p. 118).

\subsection{Conceptual Framework about Professional Identity}

From the conceptual framework among the studies in analysis arise two dimensions of identity: the individual and the collective, particularly within two professional areas teachers and nurses. The first step was to depict the similarities and dissimilarities. Afterwards it was verified in which stages of professional development identity the studies were more focused (learning stage and professional stage). Finally, we proceeded to the identification and analysis of the concepts that the authors resorted about the interpretation of professional identity.

\subsubsection{Similarities and Dissimilarities of the Conceptual Framework According to the Professional Areas}

The comparison of the studies focused on teachers with those focused on nurses, put in evidence four similarities regarding the conceptualization of professional identity: (1) importance of adopting a life style [11], which is crucial in the process of (re)construction of professional identity, and influenced by internal and external factors $[6,8]$; (2) the need to match the formative processes to the needs of practice, in order to prepare professionals capable to adapt to change and to be themselves agents of change. Thus, the notion of transformation (transform and transform himself/herself) is present in most studies, coupled with the 
Table 2. Summary Table of the typology studies (in chronological order).

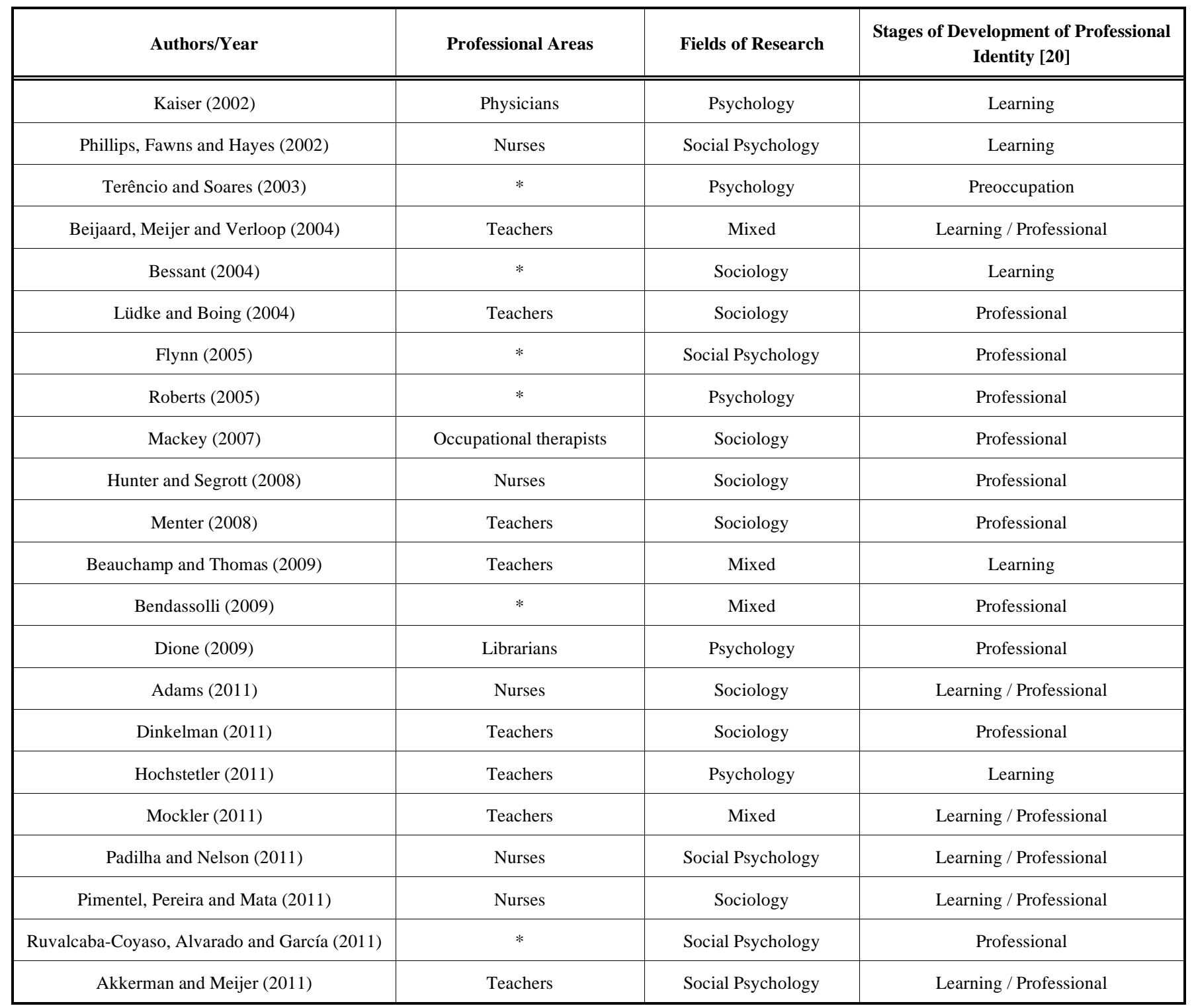

* Transversal to the different professions

ability of agency ${ }^{9}[11,46]$; (3) integration of the emotional component associated with tacit knowledge, which appears as a need felt in 'dialog' established with oneself and with others (students, patients, colleagues and families), as well as with the work context; (4) relevance of the concepts 'communities of practice' [21] and 'legitimate peripheral participation ${ }^{10}$ [47], particularly in the learning stage - when the trainer should encourage the autonomy and creativity of trainees.

Regarding dissimilarities, among the nurses' studies it was found a greater concern with the collective identity. It is likely that this is the result of its social history, acquired through biographies [35]. Indeed, there is an emphasizes to build a proper identity as an autonomous socio-professional

\footnotetext{
${ }^{9}$ Agency capability: the individual's ability to act independently in the involvement (structure) and to make his/her own decisions $[11,46]$.

${ }^{10}$ Legitimate peripheral participation: the sense of belonging to a community is developed through the relationships developed between the new elements and the older elements; learning is peripheral in the sense that new participants do a trajectory of learning to participate fully in the community of practice [47].
}

group [31], that tends to dominate more and more the knowledge (technical and relational) that was historically restricted to medicine [37]. Thus, allowing to resetting the professional limits [32]. Contrary, amongst the teachers' studies the focus was in the individual identity. It was observed: the search for the meaning of 'being a teacher' [2, 13]; the relationship between the experiences required to beginners and the competencies developed in training $[1,26$, 27]; the teachers' knowledge to face the changes of working conditions [28, 29]; and the different career moments [30].

\subsubsection{Development Stages of Professional Identity}

Taking into account the development stages of professional identity proposed by Jebril [20], it was found that the majority of studies stood at the professional level (10) and at the learning stage (5). Six of them joined these two stages together. Only one study was focused on preoccupation stage [43]. These data are patent in Table 2. 
The study focused in the preoccupation level [43] has examined the Internet use by young people. In this study they employed nicknames online to begin to view the profession choice, wish he/her might come to exercise and from which monopolise their life trajectory.

As far as the stage of learning concerns (which occurs in the context of initial training), it is understood as a crucial moment for the future professionals, not only because it provides the acquisition of a specialized knowledge, indispensable to professional recognition, but above all because it allows [1, 2, 30] - or should allow [27] - trainees to write, think and speak about professional identity. In this sense, the knowledge required to beginners, at the start of professional practice, will meet (or not) the skills developed during the prior preparation should be a concern. This enables to carry out the necessary programs' readjustment in terms of the professional identity development [1, 2, 27, 30].

In what concerns the professional stage (which occurs during the professional exercise), there are numerous internal and external factors that interfere with the professional identity; in the case of teachers, these leads them to change their way of 'thinking' and 'being a teacher' [30]. As external factors that affect the professional identity, the authors point out the influence of the increasing casualization of teaching work [28] and the sociocultural, economic and institutional power $[2,29]$. The internal factors referred are: the capacity of agency, the capacity of educational innovation and cooperation [2], the reflective capacity and motivation [30], the commitment to the profession and the emotional investment in relations that are established with the students, with the trainees at its own expense or with their colleagues, that on the whole, modify the contours of professional identity [26].

In the case of nurses, the relationship between the stage of learning and the professional stadium is echoed in dependence between the acquisition of autonomy during the initial training and the consolidation of a specialized identity during the professional exercise $[31,35,37]$. In this respect, the initial training should prepare the trainees to be autonomous professionals and to be able to follow their own paths, in order to build and consolidate a specialized knowledge that enables them to share the 'art of nursing' during the professional exercise. Pimentel, Pereira and Pereira da Mata [37] added that more than prepare for professional practice, training institutions should promote a gradual preparation for lifelong learning, which is seen as a continuous process throughout life. For Hunter and Segrott [32], it is a 'professional project' that consequently causes a large impact on professional identities, since it creates new roles and new hierarchies, which leads to the redefinition of professional limits.

\subsubsection{Conceptual Field of Professional Identity}

From the analysis of the studies, it was possible to infer that the authors, when dealing with the concept of professional identity, had their focus predominantly on one of the dimensions of identity, individual or collective, systematized by Owens, Robinson and Smith-Lovin [15]. While the social aspects of the individual dimension of identity have been addressed in studies in both professional areas, teachers and nurses, the collective dimension was especially considered in nurses' professional area. Nevertheless, the personal aspect of the individual dimension of identity was more evident for teachers within the studies focused on the internalisation of social positions and their meanings as part of the structure of the self $[1,2,27,30,36]$. The studies highlighted the critical reflection and the emotional component, both indispensable for the interaction through the relation individual ('I') / object ('me') [7].

Some authors, such as Alsup, Schön or Korthagen and Vasalos, discussed the concept of 'critical reflection'. For them, this is a concept interrelated with the emotional component. For this reason, it is heavily dependent on the personal aspect of individual identity, in particular to enable decisions about professional choices and modes of exercise. Hochstetler [27] puts emphasis on the 'critical thinking' of the trainee performing in the construction of his/her professional identity, since the trainee soon realizes what means to 'be a teacher'. Accordingly, Alsup highlights the importance of a consistent personal identity. This will help the teacher to decide about the mode of action in the classroom. When connected with the professional identity, it might lead to success at the start of the career and to the construction of professional identity in the transition from student to teacher (see Table 3). Phillips, Fawns and Hayes [36] mention the 'reflective practice' concept developed by Schön. The authors consider that this is an inadequate psychological tool when one wants to explore the meaning of the dialogs established in workplace for the construction of professional identity. Instead, the same authors propose the 'theory of positioning'. According to this theory, it is through dialog (or of discursive action, both public and private) that meanings are rebuilt and that the transformative processes happen either in trainees or institutions. Phillips, Fawns and Hayes [36] also argue that social meanings constructed in interpersonal relations imply a dynamic that the static nature and stereotyped perceptions of the theory of the role-identity ${ }^{11}$ does not seem to predict. Indeed, that 'role' symbolizes the attributes associated with a particular social position, which definitely differs from the personal characteristics of the individual who occupies this position. On the other hand, Beauchamp and Thomas [1] consider the concept of 'core reflection' of Kortagan and Vasalos as an instrument of self-reflexion with the potential to stimulate the emotional side of the individual. In this case, the reflection is often described as a cyclical model: act, last action review, being aware of essential aspects, creating alternative methods of action and judge the action. However, and in the case of teachers, there are other fundamental issues of personal character that seem to influence their practice. This is where 'core reflection' assumes a fundamental role; that is, developing a reflection that goes beyond the aspects related with the involvement, the behaviour, skills or even the beliefs. A reflection that involves

\footnotetext{
${ }^{11}$ Role-identity: "entailed the character and the role that an individual devises for himself as an occupant of a particular social position, including his imaginative view of himself as he likes to think of himself being and acting as an occupant of that position" [McCall \& Simmons, 1966, quoted by 15].
} 
Table 3. Cited Authors and Concepts Associated with Professional Identity.

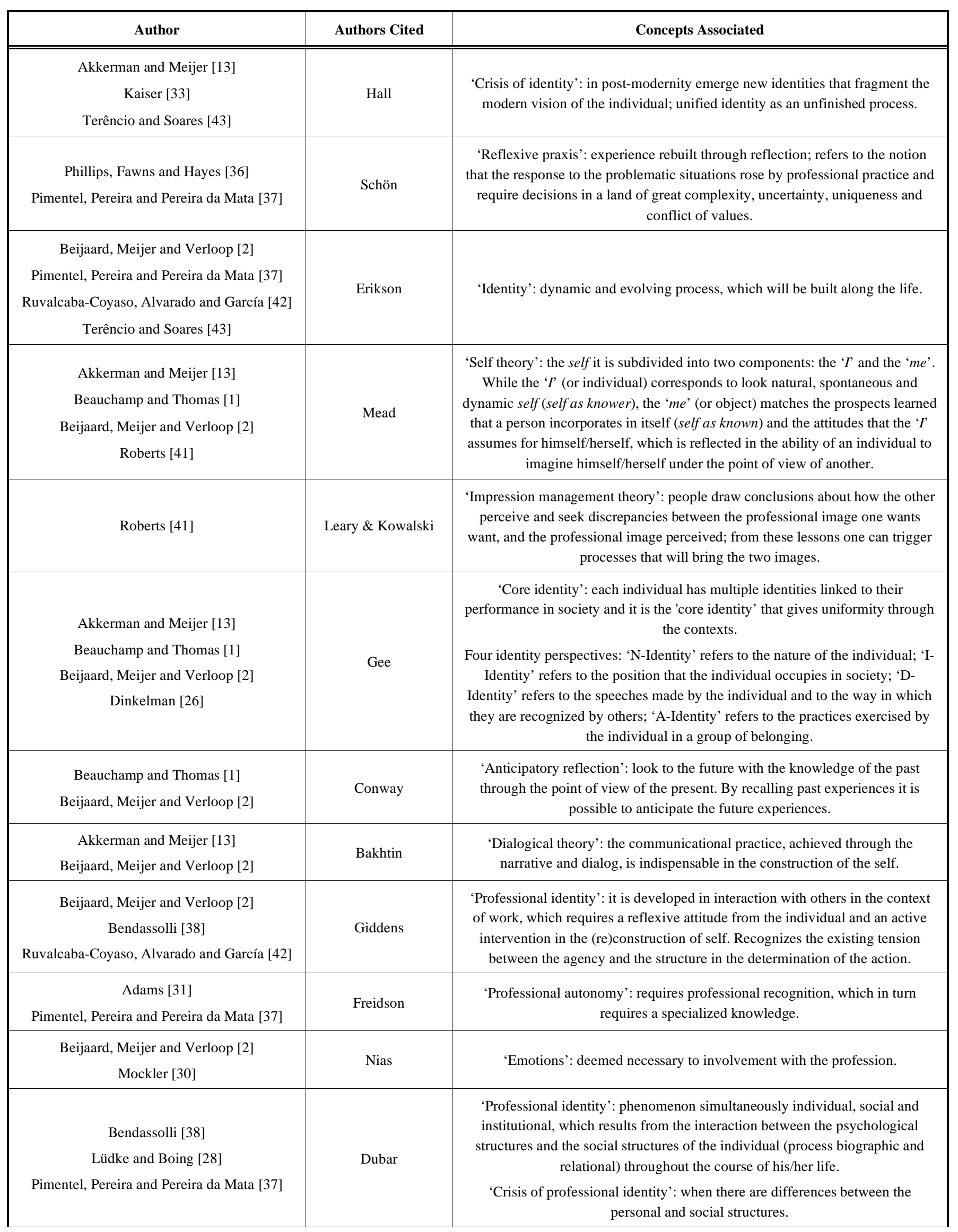


Table 3. contd...

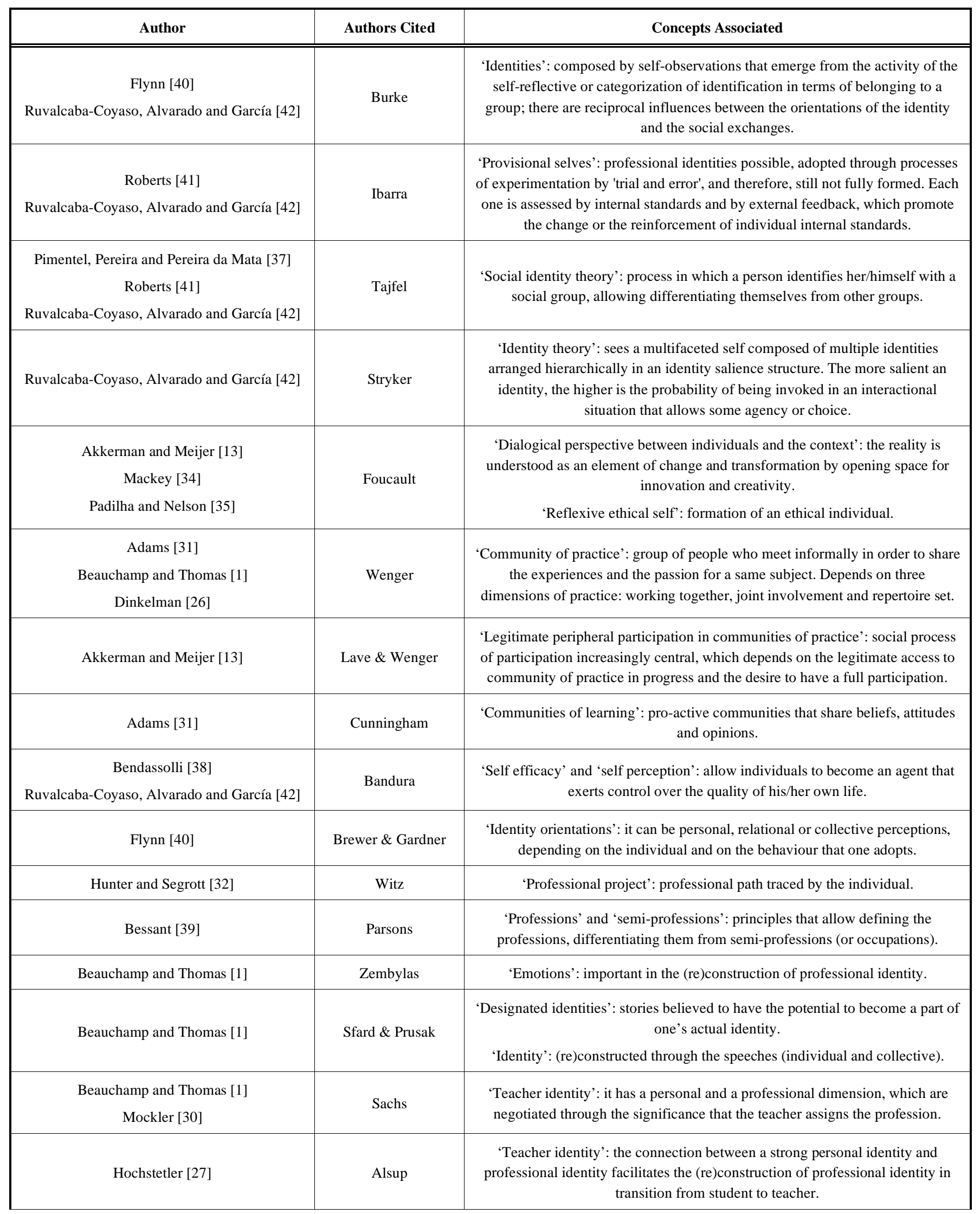


Table 3. contd...

\begin{tabular}{|c|c|c|}
\hline Author & Authors Cited & Concepts Associated \\
\hline \hline Beauchamp and Thomas [1] & $\begin{array}{c}\text { Korthagen \& } \\
\text { Vasalos }\end{array}$ & $\begin{array}{c}\text { 'Core reflection': instrument of self-reflection with the potential to stimulate the } \\
\text { emotional side. }\end{array}$ \\
\hline Mockler [30] & Lonndinin & $\begin{array}{c}\text { 'Stories to live by': the narratives counted and retold lead to the (re)construction } \\
\text { of professional identity. }\end{array}$ \\
\hline Mockler [30] & $\begin{array}{c}\text { 'Teacher identity': the perceptions from past experiences as students have } \\
\text { implications for how individuals have come to themselves as teachers. }\end{array}$ \\
\hline
\end{tabular}

the aspects related to professional identity and mission. This level of reflection, which triggers issues related with the identification with a profession, includes reflection on feelings, emotions, needs and values, and can help to turn the reflective process more spontaneous. The importance of the emotional involvement with the profession is still focused by Beijaard, Meijer and Verloop [2] and by Mockler [30], which for this purpose cite Nias.

The social aspect of individual identity with respect to the impact of cultural meanings and social situations in the identification of an individual with a group that, by involving the cultural components and situational, brings concepts related with social processes at the micro, meso and macro level [9]. In this context, Flynn [40] mentions the three guidelines of identity (personal, relational or collective) indicated by Brewer and Gardner. The differentiation of these guidelines is how the self is defined: as single individual, as a member of an interpersonal relationship or as a member of a social group. On the other hand, Flynn [40] and Ruvalcaba-Coyaso, Alvarado and García [42] quote Burke in order to state the reciprocal influences between the identity orientations and the social exchanges (related to the categorization of the self). These influences are part of the process where the identities are composed of selfobservations, emerging from the activity's reflexive 'selfcategorization' (or of 'identification') in terms of belonging to a group.

Roberts [41] mentions the 'impression management theory', of Leary and Kowalski, to clarify some social exchanges. In their point of view, regardless identity's guidelines, the individuals actively monitor the involvement in order to withdraw conclusions about the way other perceive them looking for discrepancies between the desired professional image and the professional image perceived. In this way, it is possible for them to build new identities based on the approach between those images (desired and perceived), allowing them to prosecute intentionally the control over their own life. According to Bendassolli [38] and Ruvalcaba-Coyaso, Alvarado and García [42], this social cognitive perspective is related to the concepts of "selfefficacy" and "self-perception" of Bandura. For this reason, the professional images are considered to be provisional, and fit in with the concept of 'provisional selves' of Herminia Ibarra quoted by Roberts [41] and Ruvalcaba-Coyaso, Alvarado and García [42]. Against the background of "provisional selves", the professionals adopt new identities through a process of experimentation by 'trial and error', which constitute possible professional identities and not a fully form. Each 'provisional self' is assessed by internal standards and by external feedback, which promotes the amendment or reinforces the individual internal standards.

Other studies [13, 34, 35] related to the transition between the modernity and post-modernity (quoting Foucault) consider that the individual cannot be separated from the social involvement of which is part. This looming dialectic between the individuals and the context that surrounds them is patent in the speech of Mackey [34]. For this author, biographies offer a subjective interpretation within a persons' life trajectory. On the other hand, Padilha and Nelson [35] refer to the concept of 'reflexive ethical self', conveyed by Foucault. This concept is related with an individual ethics that allows maintaining the consistency between what is said, what is being done and what one is capable of doing. Even thought the instability inherent to identity reconstruction, it is necessary to achieve a certain consistency in order to be recognized as one and the same person. For Akkerman and Meijer [13], this is possible through a dialogical approach built on the basis of the theory of dialogical self, which emerged from the connection between the theory of self of George Mead and the dialogical theory developed by Mikhail Bakhtin. By joining the concepts of self and dialog, the dialogical theory of self combines the internal space of the mind with the external relations that are established with the other through multiple 'social languages' and 'speech genres'. Even on the basis of the dialogical theory, Akkerman and Meijer [13] convey the concept of 'I-positions' - a 'voiced position'. In other words, a personality speaker is able to anticipate a point of view or a specific history. The 'I-positions' can be either internal or external: the internal corresponds to positions that the individual feels that are part of the self (e.g., I as an ambitious worker); and the external corresponds to positions that the individual feels that are part of his/her environment (e.g., my colleagues). In the same line, Akkerman and Meijer [13] believe that the continuity of the self can be guaranteed by dialogs (including the self-dialogue) and through the narratives, using, in this framework, the four perspectives of identity (natural, institutional, discursive and affinity) ${ }^{12}$ listed by Gee, that allow recognize an individual as being a certain 'kind of person' in a given context. In this vein, Beijaard, Meijer and Verloop [2] refer to the importance attributed to the sociocultural context in speeches made by people.

\footnotetext{
12 'N-Identity' refers to the nature of the individual; 'I-Identity' refers to the position the individual occupies in society; 'D-Identity' refers to the speeches made by the individual and how they are recognized by others; 'A-Identity' refers to the practices made by the individual in a belonging group [6].
} 
Beauchamp and Thomas [1] (quoting Sfard and Prusak) added the relevance of the speeches in the (re)construction of professional identity.

For Adams [31], the speeches handed down in the heart of communities, enhance the (re)construction of identities to the extent that develop standards of knowledge and learning. The author reinforces this idea by using two very close concepts: 'communities of learning' - from Cunningham -, and 'communities of practice' - from Wenger. The communities of learning are proactive communities that share beliefs, attitudes and opinions and whose elements work together, negotiating thoughts to agree on modes of action in the resolution of the problems posed by the practice. The concept of communities of practice, also used in the studies of Beauchamp and Thomas [1] and Dinkelman [26], refers to groups of people who meet together informally in order to share their experiences and passion for the same issue. These communities of practice are understood as fundamental in the training processes [31]. Indeed, these communities provide learning by approximation to practice (as is the case of professionalization) and by collaborative processes of 'situated learning', which arise from a 'legitimate peripheral participation' (concepts of Lave and Wenger cited by Akkerman and Meijer [13]). These lead to share and improve the construction of a collective knowledge.

As mentioned before, the collective identity is related to processes triggered by the level of mobilisation of the joint action and sharing ideas between the elements of a same group. According to Hunter and Segrott [32], a professional group share the same intentions when integrating a common 'professional project' (concept of Witz), and this leads to the redefinition of professional limits. Adams [31] and Pimentel, Pereira and Pereira da Mata [37] also address the issue of professional limits using the concept of 'professional autonomy' of Elliot Freidson. For the last, the professional autonomy is achieved through the professional recognition, which in turn requires technical knowledge and exclusive competence to carry out a specific function. Nevertheless, Pimentel, Pereira and Pereira da Mata [37] prefer Tajfel's 'social identity theory'. From this framework, the authors explain that a professional group tends to protect the identity of its members in order to value its uniqueness in relation to other professional groups. Still related to the recognition of professions, Bessant [39] puts into focus the distinction between 'real' professions (e.g., medicine or law) and 'semi professions' (e.g., social work, teaching or nursing). Conveyed by Parsons, Bessant [39] highlights the principles that define the 'real professions': altruism, ethics, autonomy, specialized training and control of access to knowledge.

When analysing the conceptual field, four key ideas stand out: 1) the importance of critical reflection and reflective practice - closely related to the emotional component that together allow defining the modes of being and acting. In fact, it is recognized that stimulation of the emotional side of the individual associated with a higher level of reflection ('core reflection'), promotes the involvement with the profession; 2) the individual, as an inseparable component of his/her social environment, is influenced by cultural and situational components. Moreover, the individual develops identity guidelines for social interactions that might draw conclusions about how the other(s) perceives him/her. In this context, the desire to transform the perceived images in those desired, leads the individual to create professional provisional images. However, and despite this "mutability", the individual can be recognized as a certain kind of person in a given context through the dialogs and narratives; 3 ) the speeches in communities of practice exacerbate the reconstruction of professional identity, for the reason that some patterns of knowledge and learning are developed in collaborative processes of situated learning ${ }^{13}$. The space shared promotes the construction of a collective knowledge; 4) the concern with the redefinition of professional limits and with the coveted professional autonomy requires the creation of professional projects, which allows reconstructing the collective identity.

\subsection{The Research about Professional Identity and the Implications for the Research of Teacher Professional Identity}

Recalling the third research question: What evidence have resulted from the studies conducted in the field of professional identity and what implications bring for understanding the teacher's identity? The studies were analysed in order to identify possible paths, namely methodological issues for studying the professional identity within the framework of the teaching profession. At this point, we considered not only the studies related to the teachers but also those related to nurses. Indeed, all of the studies might bring relevant data to answer the research question. In this regard, the Table $\mathbf{4}$ presents a systematization of the problems identified by the authors, the respective research proposals and the methodological suggestions; taking into account not only the purposes of the research, but also the shortages detected in the literature.

By examining the studies, certain regularity is noted among the problems identified by the authors in both professional areas (teachers and nurses). The same was not observed in regard to the research proposals and methodological suggestions. The problems identified in the studies about the teachers profession are mainly related to the scarcity of literature related to: processes of professional identity construction [30]; the need for conceptual clarification [2]; the understanding of the meaning that the teachers attribute to their own practice [13]; the established dynamic within communities of practice, in the context of professional training [26]. There were also identified problems related to the inadequacy of some training programs on the basis of the needs of the professional practice $[1,27]$, as well as with the tendency to devaluate the sociocultural teachers' roles, which determines the development of professional identity [28, 29].

The studies focused on nurses area identified the following problems: the need to redefine the professional

\footnotetext{
${ }^{13}$ Situated learning: learning that is made by new elements of communities of practice, which influences the development of each individual and the development of their own communities [47].
} 
Table 4. Problems, research proposals and methodological suggestions for future studies.

\begin{tabular}{|c|c|c|c|}
\hline Author & Problem Identified & Research Proposal & Methodological Suggestions \\
\hline Lüdke and Boing [28] & $\begin{array}{l}\text { Historical trend of devaluation of the } \\
\text { functions of teachers in society }\end{array}$ & $\begin{array}{l}\text { Research that does not restrict the practice but } \\
\text { who admire their specific knowledge of PI. }\end{array}$ & $\begin{array}{l}\text { Conceptual studies to deepen the } \\
\text { theme of PI. }\end{array}$ \\
\hline $\begin{array}{l}\text { Beauchamp and } \\
\text { Thomas [1] } \\
\text { Hochstetler [27] }\end{array}$ & $\begin{array}{c}\text { The training programs not always reveals } \\
\text { themselves appropriate to the needs of } \\
\text { the professional practice. }\end{array}$ & $\begin{array}{c}\text { Research on the relationship between the level } \\
\text { of success at the start of the practice and the } \\
\text { prior preparation, in terms of the PI } \\
\text { development. }\end{array}$ & $\begin{array}{l}\text { Longitudinal studies since the } \\
\text { formative processes until the } \\
\text { beginning of the professional } \\
\text { practice. }\end{array}$ \\
\hline Menter [29] & $\begin{array}{l}\text { The national culture traces the path of } \\
\text { teachers and influences the development } \\
\text { of its PI. }\end{array}$ & $\begin{array}{l}\text { Research that incorporates the subjective and } \\
\text { emotional dimensions, in particular the space } \\
\text { offered to creativity. }\end{array}$ & $\begin{array}{l}\text { Studies that use the observation in } \\
\text { the work context and personal } \\
\text { testimonies. }\end{array}$ \\
\hline Mockler [30] & $\begin{array}{l}\text { Little attention has been given to the } \\
\text { process of identity construction in the } \\
\text { field of education. }\end{array}$ & $\begin{array}{l}\text { Research that incorporates the personal and } \\
\text { emotional dimensions to identify the } \\
\text { differences between the levels of education, } \\
\text { between the school contexts and between } \\
\text { moments of career. }\end{array}$ & $\begin{array}{l}\text { Studies that use the observation in } \\
\text { work context. }\end{array}$ \\
\hline Dinkelman [26] & $\begin{array}{c}\text { The patterns of activity of trainers in } \\
\text { places of practice tend to be internal and } \\
\text { private. }\end{array}$ & $\begin{array}{l}\text { Research carried out by trainers themselves } \\
\text { for a better understanding of how they come } \\
\text { to themselves at their place of work, in order } \\
\text { to know about the factors that modify the PI } \\
\text { and the conditions that promote the } \\
\text { commitment with the profession. }\end{array}$ & $\begin{array}{l}\text { Studies conducted in communities } \\
\text { of practice, with the use of } \\
\text { discursive and future prospects of } \\
\text { affinity of Gee. }\end{array}$ \\
\hline $\begin{array}{c}\text { Akkerman and Meijer } \\
{[13]}\end{array}$ & $\begin{array}{l}\text { The research has perpetuated the } \\
\text { discourse about the teachers, once that } \\
\text { has been object of observation from the } \\
\text { outside. Such an approach does not allow } \\
\text { us to understand how the teachers } \\
\text { attribute meaning to their own practice. }\end{array}$ & $\begin{array}{l}\text { Search justifying empirically (in context of } \\
\text { practice) the current vision of teachers PI. }\end{array}$ & $\begin{array}{l}\text { Studies that use the observation in } \\
\text { the work context and the 'self } \\
\text { dialogues' of teachers (novice and } \\
\text { expert). }\end{array}$ \\
\hline $\begin{array}{l}\text { Beijaard, Meijer and } \\
\text { Verloop [2] }\end{array}$ & $\begin{array}{l}\text { Different concepts have been used to } \\
\text { indicate the same thing, or whose } \\
\text { relationship has not been clarified. }\end{array}$ & $\begin{array}{l}\text { Research about the relationship between the } \\
\text { concepts of identity and self and about the } \\
\text { context influence of what account as } \\
\text { 'professional' in the (re)construction of the } \\
\text { teachers PI. }\end{array}$ & $\begin{array}{c}\text { Studies of nature conceptual and } \\
\text { empirical studies that combine the } \\
\text { cognitive and sociological } \\
\text { perspectives. }\end{array}$ \\
\hline $\begin{array}{l}\text { Hunter and Segrott } \\
\qquad[32]\end{array}$ & $\begin{array}{l}\text { Lack of autonomy of nurses in the } \\
\text { resolution of the problems posed by the } \\
\text { practice. }\end{array}$ & $\begin{array}{l}\text { Search in places of work that find 'evidence' } \\
\text { in health care and questioning the } \\
\text { generalisation of professional paths. }\end{array}$ & $\begin{array}{l}\text { Ethnographic studies that support } \\
\text { the impact of vocational pathways } \\
\text { of nurses in their decision-making } \\
\text { capacity. }\end{array}$ \\
\hline Mackey [34] & $\begin{array}{l}\text { Scarcity of literature about the } \\
\text { redefinition of professionals emerging as } \\
\text { reflective professionals, ethical and as } \\
\text { active agents. }\end{array}$ & $\begin{array}{l}\text { Research in workplaces that allow knowing } \\
\text { how the professionals create their own career } \\
\text { path. }\end{array}$ & $\begin{array}{l}\text { Studies that use the observation in } \\
\text { the workplace to meet the nature } \\
\text { of discourse in finding new } \\
\text { meanings. }\end{array}$ \\
\hline $\begin{array}{l}\text { Phillips, Fawns and } \\
\text { Hayes [36] }\end{array}$ & Need to redefine professional boundaries. & $\begin{array}{l}\text { Search in places of work taking into account } \\
\text { three domains of practice: the discursive } \\
\text { action (both public and private), the agency } \\
\text { and structure. }\end{array}$ & $\begin{array}{l}\text { Studies in communities of practice } \\
\text { and use of 'self dialogues '. }\end{array}$ \\
\hline $\begin{array}{l}\text { Pimentel, Pereira and } \\
\text { Pereira da Mata [37] }\end{array}$ & $\begin{array}{l}\text { The moral and social values, as well as } \\
\text { the relationship between the theoretical } \\
\text { and practical knowledge resulted in } \\
\text { action strategies that constrain the } \\
\text { autonomy and, consequently, the PI. }\end{array}$ & $\begin{array}{l}\text { Research within work places that allow } \\
\text { understanding the nature of health care to act } \\
\text { in the construction of specialized knowledge }\end{array}$ & $\begin{array}{l}\text { Qualitative studies to understand } \\
\text { the nature of health care. }\end{array}$ \\
\hline
\end{tabular}


Table 4. contd...

\begin{tabular}{|c|c|c|c|}
\hline Author & Problem Identified & Research Proposal & Methodological Suggestions \\
\hline \hline $\begin{array}{c}\text { Padilha and Nelson } \\
\text { [35] }\end{array}$ & $\begin{array}{c}\text { Understand the collective identity } \\
\text { through the history of nursing. }\end{array}$ & $\begin{array}{c}\text { Research to increase the knowledge about the } \\
\text { construction of the PI, which will encourage } \\
\text { the trainers as future professionals to build } \\
\text { their own knowledge (explicit/tacit consent). }\end{array}$ & $\begin{array}{c}\text { Biographical studies to understand } \\
\text { how different interpretations are } \\
\text { constructed. }\end{array}$ \\
\hline Adams [31] & $\begin{array}{c}\text { The historical perspective of the role } \\
\text { played by nurses exerts the need for } \\
\text { autonomy. }\end{array}$ & Research about the professionalism and \\
professional status. & $\begin{array}{c}\text { Qualitative studies that permit to } \\
\text { observe the principles that } \\
\text { promote tacit knowledge. }\end{array}$ \\
\hline Roberts [41] & $\begin{array}{c}\text { Identifying strategies that will construct } \\
\text { positive images during the interactions } \\
\text { established at different career stages. }\end{array}$ & $\begin{array}{c}\text { Research about the impact of identities } \\
\text { (personal and social) in the construction of the } \\
\text { professional image in different professions. }\end{array}$ & $\begin{array}{c}\text { Qualitative studies to find how and } \\
\text { why individuals are strategically in } \\
\text { different situations. }\end{array}$ \\
\hline $\begin{array}{c}\text { Flynn [40] } \\
\text { promoting changes in the guidelines of } \\
\text { identity in view of the employee } \\
\text { satisfaction and the success of } \\
\text { organizations. }\end{array}$ & $\begin{array}{c}\text { Research about the change in the identity } \\
\text { guidelines and the social interactions } \\
\text { preferences. }\end{array}$ & $\begin{array}{c}\text { Studies that use the observation in } \\
\text { work context. }\end{array}$ \\
\hline $\begin{array}{c}\text { Ruvalcaba-Coyaso, } \\
\text { Alvarado and García } \\
\text { [42] }\end{array}$ & $\begin{array}{c}\text { Scarcity of longitudinal investigation } \\
\text { about the PI. }\end{array}$ & $\begin{array}{c}\text { Search that allows configuring the PI in } \\
\text { function of the meanings assigned and of } \\
\text { social constructions. }\end{array}$ & $\begin{array}{c}\text { Longitudinal studies that combine } \\
\text { cognitive and sociological } \\
\text { perspectives. }\end{array}$ \\
\hline
\end{tabular}

limits [36], the lack of autonomy [31, 32, 37], the need to know more about the collective identity [35], and the shortage of literature related to the way the professionals are redefined in order to emerge as reflective professionals [34].

With regard to the research proposals, and in an attempt to inject new and renewed understandings of the process of (re)construction of professional identity, the authors suggest investigations within workplaces, that incorporate the subjective and emotional dimensions, in particular the space offered to creativity $[29,30,32,36]$, and to understand not only how to build a professional identity [35], but also how the professional path is traced [34]. Additionally, they propose researches that establish the relationship between the level of success at the start of the professional practice and the prior preparation [1, 27], as well as surveys among trainers to understand how they see themselves in the workplace [26]. In this way, it might be possible to operate in the construction of specialized knowledge [37].

Finally, in terms of methodological suggestions, some studies $[1,27,28]$ pointed out the need to carry out more research in the conceptual scope that incorporates the specific expertise of professional identity or that focus on the complexity of its development. In other studies $[2,31]$, it is referred the need to investigate the level of theory about specific issues such as the relationship between the concepts of identity and self or the study of the principles that promote the tacit knowledge. However, the proposal to carry out empirical studies using qualitative methodologies is patent in the majority of the studies. In fact, some of these studies indicate the direct observation in the contexts of practice to investigate the subjective and emotional dimensions [29], in order to understand 'what works' for the quality teaching [30], and 'what counts as professional' in the (re)construction of professional identity [2].
In Akkerman and Meijer's [13] perspective, the research produced has perpetuated the discourse about the teachers. For the same authors, such an approach does not allow understanding how teachers attribute meaning to their own practice. That is, the importance given to teachers' 'selfdialogues' (novice and expert) and how they solve the doubts and dilemmas that arise in normal working routines, (a combination between micro and macro analysis ${ }^{\mathrm{P}}$ ) is yet to understand. In the same way, Dinkelman [26] and Phillips, Fawns and Hayes [36] advocate the use of these two levels of analysis. Thus, Dinkelman proposes the use of discursive and future prospects of affinity of Gee, in communities of practice, in a survey carried out within the trainers to know the factors that affect their professional identity and the conditions that promote the commitment with the profession. On the other hand, Phillips and his colleagues suggest that it is necessary to listen 'self-dialogues' and to observe the dynamic established in the communities of practice, taking into account the discursive action (both public and private), the agency and the structure.

Beijaard, Meijer and Verloop [2], besides proposing studies using qualitative methodologies, specify the use of cognitive perspective ${ }^{15}$ and sociological perspective ${ }^{16}$. Roberts [41] and Ruvalcaba-Coyaso, Alvarado and García [42] have the same perspective. In the authors' view, the combination of these two perspectives will depict, for example, what is the influence of the context on the

\footnotetext{
${ }^{14}$ Microanalysis: relationships established in the workplace (e.g. students, colleagues, families); macro analysis: everything that goes beyond the 'here and now', taking into account the 'self-dialogues ' of teachers in terms of the past and future prospects, as well as the sociocultural determinants of involvement [13].

${ }^{15}$ Cognitive perspective: it incorporates the idea that personal identity and social identity of a person are stored in separate cognitive structures, even though these constructs are strongly interrelated [48].

${ }^{16}$ Sociological perspective: "the self is something that arises in the process of social experience and activity, that is, develops in the given individual as a result of his relations to that process as a whole and to other individuals within that process". [7].
} 
(re)construction of professional identity or what is the impact of individual identity (personal and social aspects) in the (re)construction of professional image. Additionally, it can define the professional identity as a function for the assigned meanings and social constructions. For Ruvalcaba-Coyaso, Alvarado and García [42], longitudinal studies are also needed, since professional identity is understood as a set of observable processes over the years. Within this perspective, it is argued by Hunter and Segrott [32] that this studies' typology allow understanding the impact of vocational pathways in the ability to take decisions, which are indispensable for the acquisition of autonomy in the resolution of problems. By electing direct observation of specific behaviours, it will be possible to deepen the knowledge of how to act in practice conditions, in order to promote changes in the identity orientations. And this will promote the satisfaction of the professionals and the success of organizations [40]. On the other hand, acting within practice conditions may promote the construction of professional knowledge in search of new meanings, emerging as reflective professionals and as active agents [34, $35,37]$. The knowledge about professional identity (re)construction is of great interest to trainers and for the development of the profession, in so far as trainers may encourage future professionals to build their own knowledge, be it explicit or tacit [35].

\section{CONCLUSION}

In the introductory chapter were placed three research questions that guided this study. In terms of the typology of the studies, it was evident that the number of articles published between 2002 and 2011 about the professional identity has suffered a marked increase in 2011. The interest in the publication of articles of conceptual nature still reveals an intense concern of the academic community by this issue. We identified two major professional areas (teachers and nurses) and two main stages of development, in which the studies focus: the learning and professional process. The fields of research were different (philosophical, psychological, sociological, historical and anthropological). Regarding the theoretical perspectives adopted, it is possible to observe a strong positioning of the authors within the symbolic interactionism and post-modernity. Accordingly, the professional identity is a process that begins in childhood, where children begin to foresee the choice of a profession. Additionally, even though professional identity is self-evolutionary, it is also a consistent process that is (re)constructed in the interaction with others and within the environment.

With regard to conceptual framework and the understandings that shape the research, it was evident that the concept of professional identity fits simultaneously in individual and collective dimensions [15]. Indeed, not only it is constituted by social identities of a person (when this person identifies with a professional group and when he assumes the respective role), but also mobilizes a joint action (when there is a sense of common destiny within the group). The personal aspect of the individual dimension incorporates the critical reflection and the emotional component, while the social aspect involves the cultural and situational components. For its part, the collective dimension concerns the professional group, because it shares the same goals. This can happens through the creation of a professional project, in order to promote the development of the profession and its development in society. According to this conceptual framework, an individual can choose three guidelines of identity (personal, relational or collective), depending on the mode the self is defined (individual, member of an interpersonal relationship or member of a social group). The guidelines of identity may change according to the situation. Nevertheless, self's continuity will be guaranteed by speeches (public or private). In this context, the speeches created among communities of practice are understood as fundamental during the stage of learning. In fact, it is through collaborative processes of situated learning and of legitimate peripheral participation that knowledge it is not only shared but also a way to improve the individual and collective wisdom.

In what concerns the evidence found and the indications for future investigations about teacher's identity, some authors suggest the need for further studies of conceptual nature that deepen the complexity of professional identity construct. However, the majority considers that it is necessary to carry out empirical studies using qualitative methodologies, namely 'self-dialogues' and direct observation in the contexts of practice to search for the subjective and emotional dimensions, a combination between micro and macro analysis. The research on communities of practice, using the discursive and affinity perspectives proposed by Gee [6], are also pointed out as paths to follow to understand in greater depth the factors that change the teacher professional identity and the conditions that promote the engagement with the profession. Once the (re)construction of the teacher's identity can be understood as a set of observable processes over the years, longitudinal studies of ethnographic nature are also suggested. Thus, it is possible to state that a combination of cognitive and sociological perspectives, will contribute for the comprehension of the context influence for the (re)construction of teacher identity, and thus for a better understanding of the processes of identity reconfiguration and the assigned meanings.

\section{CONFLICT OF INTEREST}

The authors confirm that this article content has no conflict of interest.

\section{ACKNOWLEDGEMENTS}

Research Project funded by Foundation for Science and Technology, reference PTDC/DES/115922/2009.

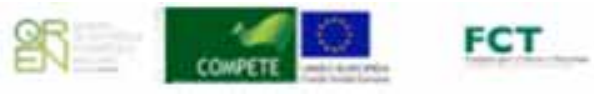

\section{REFERENCES}

[1] Beauchamp C, Thomas L. Understanding teacher identity: an overview of issues in the literature and implications for teacher education. Camb J Educ 2009; 39(2): 175-89.

[2] Beijaard D, Meijer PC, Verloop N. Reconsidering research on teachers' professional identity. Teach Teach Educ 2004; 20(2): 107-28. 
[3] Dornan T, Littlewood S, Margolis SA, Scherpbier A, Spencer J, Ypinazar V. How can experience in clinical and community settings contribute to early medical education? A BEME systematic review. Med Teach 2006; 28(1): 3-18.

[4] Mockler N. Trans/forming Teachers: New Professional Learning and Transformative Teacher Professionalism. J In-service Educ 2005; 31(4): 733-46.

[5] Reid A, Dahlgren LO, Petocz P, Dahlgren MA. Identity and engagement for professional formation. Stud High Educ 2008; 33(6): 729-42.

[6] Gee JP. Identity as an Analytic Lens for Research in Education. Rev Res Educ 2001; 25: 99-125.

[7] Mead GH. Mind, Self and Society. Chicago: The University of Chicago Press 1962.

[8] Dubar C. A Socialização: Construção das Identidades Sociais e Profissionais. Porto: Porto Editora 1997.

[9] Stets JE, Burke PJ. Identity Theory and Social Identity Theory. Soc Psychol Q 2000; 63(3): 224-37.

[10] Castells M. The Power of Identity. $2^{\text {nd }}$ ed. Oxford: WileyBlackwell 1997.

[11] Giddens A. Modernidade e Identidade Pessoal. $2^{\text {nd }}$ ed. Oeiras: Celta Editora 1997.

[12] Durkheim É. La enseñanza de la moral en la Escuela Primaria. Rev Esp Investig Soc 2000; (90): 275-87.

[13] Akkerman SF, Meijer PC. A dialogical approach to conceptualizing teacher identity. Teach Teach Educ 2011; 27(2): 308-19.

[14] Enyedy N, Goldberg J, Welsh KM. Complex dilemmas of identity and practice. Sci Educ 2006; 90(1): 68-93.

[15] Owens TJ, Robinson DT, Smith-Lovin L. Three faces of identity. Ann Rev Sociol 2010; 36: 477-99.

[16] Conway PF. Anticipatory reflection while learning to teach: From a temporally truncated to a temporally distributed model of reflection in teacher education. Teach Teach Educ 2001; 17(1): 89-106.

[17] Sfard A, Prusak A. Telling identities: In search of an analytic tool for investigating learning as a culturally shaped activity. Educ Res 2005; 34(4): 14-22.

[18] Flores MA, Day C. Contexts which shape and reshape new teachers' identities: a multi-perspective study. Teach Teach Educ 2006; 22: 219-32.

[19] Marcelo C. Desenvolvimento Profissional Docente: passado e futuro. Sísifo Rev Ciên Educ 2009; (8): 7-22.

[20] Jebril MY The evolution and measurement of professional identity. PhD., Disseration. The Graduate School of the Texas Woman's University, College of Health Sciences 2008.

[21] Wenger E. Communities of practice: Learning, meaning and identity. $17^{\text {th }}$ ed. New York: Cambridge University Press 1998.

[22] Major CH, Savin-Baden M. Qualitative research synthesis: the scholarship of integration in practice. In: Major $\mathrm{CH}$, Savin-Baden M, editors. New approaches to qualitative research : wisdom and uncertainty. Abingdon, Routledge 2010; pp. 108-18.

[23] Petticrew M, Roberts H. Systematic reviews in the social sciences: a practical guide. Malden: Blackwell Publishing 2006.

[24] Bolívar A, Domingo J, Fernández M. La investigación biográficonarrativa en educación. Guía para indagar en el campo. Granada: Universidad de Granada 1998.

[25] Bendle MF. The crisis of 'identity' in high modernity. Br J Soc 2002; 53(1): 1-18.

[26] Dinkelman T. Forming a Teacher Educator Identity: uncertain standards, practice and relationships. J Educ Teach 2011; 37(3): 309-23.

[27] Hochstetler S. Focus on Identity Development: A Proposal for Addressing English Teacher Attrition. Clear House 2011; 84(6): 256-9.
[28] Lüdke M, Boing LA. Caminhos da profissão e da profissionalidade docentes. Educ Soc 2004; 25(89): 1159-80.

[29] Menter I. Tradition, culture and identity in the reform of teachers' work in Scotland and England: some methodological considerations. Pedagogy Cult Soc 2008; 16(1): 57-69.

[30] Mockler N. Beyond 'what works': understanding teacher identity as a practical and political tool. Teach Teach 2011; 17(5): 517-28.

[31] Adams R. Exploring dual professional identities, the role of the nurse tutor in higher education in the UK: role complexity and tensions. J Adv Nurs 2011; 67(4): 884-92.

[32] Hunter B, Segrott J. Re-mapping client journeys and professional identities: A review of the literature on clinical pathways. Int $\mathbf{J}$ Nurs Stud 2008; 45(4): 608-25.

[33] Kaiser R. Fixing Identity by Denying Uniqueness: An Analysis of Professional Identity in Medicine. J Med Hum 2002; 23(2): 95-105.

[34] Mackey H. 'Do not ask me to remain the same': Foucault and the professional identities of occupational therapists. Aus Occup Ther J 2007; 54(2): 95-102.

[35] Padilha MI, Nelson S. Networks of Identity: The Potential of Biographical Studies for Teaching Nursing Identity. Nurs Hist Rev 2011; 19: 183-93.

[36] Phillips D, Fawns R, Hayes B. From personal reflection to social positioning: the development of a transformational model of professional education in midwifery. Nurs Inq 2002; 9(4): 239-49.

[37] Pimentel MH, Pereira FA, Pereira da Mata MA. La construcción de la identidad social y profesional de una profesión femenina: enfermería. Prisma Soc 2011; (7): 1-23.

[38] Bendassolli PF. Reconstruction of the subject-work relationship in the emerging models of career. Rae-Rev Admin Empres 2009; 49(4): 387-400.

[39] Bessant J. Youth work: the Loch Ness monster and professionalism. Youth Studies Australia 2004; 23(4): 26-33.

[40] Flynn FJ. Identity Orientations and Forms of Social Exchange in Organizations. Acad Manage Rev 2005; 30(4): 737-50.

[41] Roberts LM. Changing Faces: Professional Image Construction in Diverse Organizational Settings. Acad Manage Rev 2005; 30(4): 685-711.

[42] Ruvalcaba-Coyaso J, Alvarado JU, García RG. Identidad e identidad profesional: Acercamiento conceptual e investigación contemporánea. Rev CES Psicol 2011; 4(2): 82-102.

[43] Terêncio MG, Soares DHP. A Internet como ferramenta para o desenvolvimento da identidade profissional. Psicol Est 2003; 8(2): 139-45.

[44] Dione B. Identité et valeurs profissionelles: aux fondements de l'éthique de la profession de bibliothécaireProfessional identity and professional values: revisiting librarian professional ethics foundations. Encon Bibli [serial on the Internet]. 2009 [cited 2012 december 12]; (Especial+1/2009): 144. Available from: http://www.redalyc.org/articulo.oa?id=14712771010.

[45] Lopes A. La construcción de identidades docentes como constructo de estrutura y dinámica sistémicas: argumentación y virtualidades teóricas y prácticas. Prof Rev Currícul Form Prof [serial on the Internet]. 2007 [cited 2010 november 9]; 11(3): 1. Available from: http://www.ugr.es/ recfpro/rev113COL1.pdf.

[46] MacPhail A, Tannehill D. Helping Pre-Service and Beginning Teachers Examine and Reframe Assumptions About Themselves as Teachers and Change Agents: "Who is Going to Listen to You Anyway?". Quest 2012; 64(4): 299-312.

[47] Lave J, Wenger E. Situated Learning: Legitimate Peripheral Participation. New York: Cambridge University Press 1991.

[48] Trafimow D, Triandis HC, Goto SG. Some tests of the distinction between the private self and the collective self. J Pers Soc Psychol 1991; 60(5): 649-55

(C) Cardoso et al.; Licensee Bentham Open.

This is an open access article licensed under the terms of the Creative Commons Attribution Non-Commercial License (http://creativecommons.org/licenses/ by-nc/3.0/) which permits unrestricted, non-commercial use, distribution and reproduction in any medium, provided the work is properly cited. 